\title{
Gerak Kapital Industri Media Nasional
}

\author{
Bestian Nainggolan \\ Litbang Kompas Universitas Indonesia \\ Email: bestian.nainggolan@kompas.com/djulibestian41@ui.ac.id
}

\begin{abstract}
Abtract
External macro of media political changing and communication technology has been becoming typical factors which reshape the pattern of accumulativa capital in media industri in this country. This article tries to explore and explain how 13 groups of national media corporation implement management strategies and capital flow as the responses toward external media changing since in 1998. This accumulatian can be seen by ownship media concentration which was integrated either vertically or horisontally even cross media integration. After a decade of Reformation Era 1998, each of media group tried to push his capital that was owned very expansive and they integrated every single of media capital into one economic power within one of conglomeration. But a decade later, this was changing. Three format of media capital flow then were established as following as: stagnant media corporation; slowly media corporation flow and expansive media capital flow with specificly capital. This implied to new problems in line to how media corporation in Indonesia managed.
\end{abstract}

Keywords: Media industry, integration, capital, corportation and technology

\begin{abstract}
Abstrak
Perubahan eksternal makro politik media dan teknologi komunikasi menjadi faktor tipikal yang mengubah pola pengakumulasian kapital industri media di negeri ini. Paper ini berupaya mengeksplorasi dan menjelaskan, bagaimana 13 grup korporasi media nasional menjalankan strategi pengelolaan maupun pergerakan kapitalnya sebagai respons terhadap arus perubahan eksternal media yang berlangsung semenjak tahun 1998.Pengakumulasian kapital media pada setiap grup korporasi media berlangsung melalui pola pengkonsentrasian kepemilikan media yang terintegrasi secara secara horizontal (horizontal integration), vertikal (vertical integration), maupun diagonal (cross-media integration). Selepas tahun 1998, setiap grup korporasi media berupaya menggerakkan kapital yang dimilikinya dengan sangat ekspansif dan mengintegrasikan segenap kapital media tersebut dalam kendali grup konglomerasi. Namun satu dasa warsa kemudian, cenderung berubah. Tiga format gerak kapital yang kemudian terbentuk, yaitu: korporasi media yang mengalami stagnasi ekspansi kapital, korporasi media dengan pergerakan kapital yang melambat, dan korporasi media dengan pergerakan kapital yang tetap ekspansif namun terfokus pada beberapa jenis kapital media. Perubahan pengelolaan dan pergerakan kapital industri tersebut membuka ruang persoalan baru terkait masa depan corak kapitalisme industri media di negeri ini.
\end{abstract}

Kata Kunci: industri media, integrasi, kapital, korporasi, teknologi 


\section{Pendahuluan}

Perubahan kondisi makro politik media dan perubahan teknologi komunikasi menjadi dua faktor tipikal yang secara simultan hadir dalam kehidupan industri media di negeri ini. Kedua faktor tersebut turut mendorong terbentuknya pergerakan kapital industri media.

Peran kedua faktor tersebut dijelaskan sebagai berikut. Di satu sisi, perubahan kondisi makro politik yang berlangsung sejalan dengan liberalisasi politik 1998, memberikan ruang kebebasan pada setiap sendi kehidupan ekonomi industri media di negeri ini. Liberalisasi berlangsung diikuti oleh langkah-langkah deregulasi (Pencabutan Permenpen No.1 1984 tentang SIUPP, kemunculan UU No 40 1999 tentang Pers) maupun debirokratisasi kehidupan ekonomi politik industri media (Pembubaran Departemen Penerangan). Dalam kondisi tersebut, apabila sebelumnya, negara menjadi sentral kehidupan ekonomi politik media, menjadi sumber utama kapital industri sekaligus pengontrol informasi pers (Dhakidae, 1991; Hanazaki, 1998; Sen \& Hill, 2000), beralih menjadi sosok negara yang cenderung membebaskan berbagai barriers to entry struktur pasar industri media dan mengarahkan pada corak industri media yang neoliberalis (Ishadi, 2002; Triputra, 2004; Armando, 2006, 2016).

Liberalisasi memicu pergerakan masif kapital media dalam format pendirian media baru. Sebagai gambaran, jika tahun 1997 hasil penginventarisasian Departemen Penerangan (1998) menunjukkan terdapat 289 media cetak, 379 radio, dan 5 stasiun televisi, maka satu dasa warsa kemudian bertumbuh menjadi 851 media cetak, 1022 radio, dan 10 televisi (Aliansi Jurnalis Independen, 2007). Terakhir, hasil pendataan Dewan Pers (2015) menunjukkan terdapat 320 media cetak, 674 radio, 523 stasiun televisi (nasional, lokal, jaringan), dan 68 media online.

Dalam perkembangannya, liberalisasi tidak selalu mendorong terciptanya demokratisasi media. Liberalisasi media justru melahirkan pembentukan struktur pasar industri media yang bersifat distortif. Pertumbuhan pesat media pada kenyataannya hanya terkonsentrasi pada sebagian kecil kepemilikan. Dalam berbagai kajian, secara nasional tidak kurang hanya 13 grup korporasi konglomerasi media yang menguasai sebagian besar media di negeri ini (Nugroho, dkk, 2012; Lim, 2012). Dari ke-13 grup konglomerasi tersebut jika dikaji lebih lanjut pola penguasaan pasarnya, menunjukkan corak oligopolistik struktur pasar industri media, oleh karena terfokus pada penguasaan pasar iklan dan audiens media pada beberapa grup saja, yaitu Grup Global Mediacom dan Grup Elang Mahkota Teknologi pada industri televisi, serta Grup Jawa Pos dan Kompas Gramedia pada industri media cetak (Nainggolan, 2015).

Pada pemandangan lain, arus perubahan teknologi komunikasi yang berlangsung juga signifikan dalam mempengaruhi gerak kapital industri media. Perubahan teknologi komunikasi yang terformulasikan dalam konsep digitalisasi media, telah memfasilitasi tergerusnya batasbatas yang dimiliki media selama ini. Digitalisasi membuat pola produksi, distribusi, dan konsumsi pada media cetak maupun penyiaran yang sebelumnya terpisah-pisah (analog) dalam pola single-platform, menjadi terintegrasi dalam pola multi-platform. Perubahan teknologi komunikasi digital tersebut membuat format kekinian industri media global terwujud dalam bentukbentuk konvergensi media (Negroponte, 1979; Pool, 1983; Wirtz, 2001; Soo Chon, dkk, 2003; Jenkins, 2006).

Di sisi lain, berlangsungnya transformasi media ke dalam bentuk-bentuk digital juga dipandang sebagai jawaban bagi problem pengelolaan kapital industri media. Kondisi yang berlangsung, dengan berbagai pertimbangan rasional, antara lain kondisi semakin menurunnya konsumen media analogtradisional, upaya memperluas pasar audiens maupun pengiklan, dan teknologi konvergensi potensial meningkatkan efisiensi produksi, maka transformasi teknologi media dilakukan (Deuze, 2004; Klinerberg, 2005). Seperti juga yang berlangsung secara global, digitalisasi media 
menjadi bagian dari kehidupan industri media di negeri ini. Berbagai bentuk adaptasi perubahan teknologi dilakukan, baik dari sisi penciptaan media-media baru yang berbasis teknologi digital interaktif dan pengadopsian pola kerja konvergensi media (Aliansi Jurnalis Independen, 2012).

Dua faktor di atas, menunjukkan bahwa liberalisasi politik yang membebaskan kehidupan ekonomi politik media dan teknologi komunikasi (digitalisasi media) dengan segenap perkembangannya, secara simultan justru menjadi pendorong gerak kapitalisme industri media di negeri ini. Namun, bagaimana jalannya pergerakan kapital industri media itu berlangsung dan dalam bentuk-bentuk pengelolaan kapital seperti apa yang dipraktikkan masing-masing korporasi media di negeri ini?

Paper ini berupaya menjelaskan dinamika kapital, baik gerak dan corak perkembangan kapital industri media di negeri ini yang berlangsung masif semenjak tahun 1998. Selain memaparkan gerak dan keragaman corak kapital media, kajian ini pun menguak sisi kritis pengelolaan kapital pada sebagian besar pelaku industri media, yang membuka ruang persoalan baru terkait kemungkinan-kemungkinan terbentuknya corak baru pergerakan kapital masa depan industri media nasional.

Dalam sistem produksi masyarakat kapitalistik, Karl Marx (1867, 1883, 1885, 1997) menegaskan bahwa kapital menjadi konsep sentral dari suatu cara produksi (mode of production). Dalam hal ini, penguasaan kapital merupakan penentu dari relasi produksi yang ditujukan sebagai penciptaan "surplus nilai". Menurut Marx, surplus nilai dihasilkan oleh para penguasa kapital dari relasi kerja produksi yang tidak seimbang, cenderung eksploitatif terhadap posisi kehidupan pekerja atau faktor produksi lainnya. Surplus nilai yang dihasilkan, selain digunakan untuk konsumsi para penguasa kapital, sebagian akan dikembalikan menjadi bentuk kapital, direproduksi, dan kembali menghasilkan surplus nilai baru. Dalam pengamatan Marx, proses pengakumulasian kapital semacam ini berkesinambungan dalam suatu proses yang ia sebut "sirkuit perputaran kapital".

Berdasarkan konsep kapital, produksi, reproduksi, surplus nilai, sirkuit perputaran kapital itulah pemahaman kapitalisme sebagai suatu sistem ekonomi dikenalkan. Intinya, kapitalisme merujuk pada suatu sistem ekonomi yang bersandar pada upaya penciptaan surplus nilai yang berulang. Penopang kondisi tersebut harus dikarakteristikkan adanya pengakuan terhadap kepemilikan privat, kebebasan dalam persaingan pasar, dan rasionalitas. Namun, sebagaimana yang ditambahkan Luxemberg (1913, 2003), bahwa skema reproduksi kapitalisme murni Marx tersebut harus bersifat terbuka dan mengkaitkan berbagai elemen lain di luar sistem produksi yang berlangsung sehingga proses kapitalisme (ekspansi kapital) semakin meluas, bahkan mengglobal.

Dengan konsep demikian, maka dalam sistem kapitalisme, kapital harus bergerak (digerakan) dan bekerja dalam berbagai usahausaha produktif agar surplus nilai diperoleh. Kapital yang tidak diproduktifkan merupakan kapital yang "mati" yang dinilai tidak hanya membahayakan para pemilik kapital namun juga bagi sistem ekonomi serta masyarakat (Knoche, 1999).

Perkembangan media sebagai institusi ekonomi juga tidak lepas dari prinsip dan pola kapitalisme (Schiller, 1969; Kellner, 1990; Murdock, 1990; McChesney, 2008; Suarez-Villa, 2015). Penciptaan suplus nilai dalam industri media dihasilkan dari rangkaian proses produksi informasi yang melibatkan kapital media, tenaga kerja, dan alat kerja. Sirkuit perputaran kapital media dikatakan berlangsung, tatkala surplus nilai yang dihasilkan kembali direproduksi sebagai kapital media yang selanjutnya digunakan untuk menciptakan kembali surplus nilai.

Sebagai elaborasinya, Knoche (1999) memilah kapital yang digunakan dalam industri media dalam empat tipe. Pertama, kapital media tergolong inti (media capital) dalam arti surat kabar, majalah, buku, radio, televisi, film, video, yang didalamnya terjadi proses pemroduksian 
teks, gambar, dan suara. Kapital media semacam ini bersifat aktif dan memiliki nilai yang mampu ditingkatkan. Kedua, kapital yang disebut sebagai media-oriented capital dalam arti kapital yang nilai keberadaannya diorientasikan bagi media (kapital media). Entitas pra produksi seperti kertas bagi media cetak, mesin cetak, tinta, hingga lini post produksi seperti agen distribusi, agen iklan, marketing, riset pasar, tergolong dalam tipe kapital semacam ini. Ketiga, kapital dalam pemahaman yang lebih luas, yaitu kapital media infrastructure. Termasuk di dalam kelompok kapital ini adalah jaringan telepon, infrastruktur kabel, satelit, komputer hingga internet. Keempat, kapital yang disebut mediaexternal capital. Termasuk dalam kapital ini semua sektor-sektor ekonomi yang berkaitan dengan media, seperti perbankan, asuransi, penyuplai energi, transport, ataupun industri properti. Semua sektor tersebut terkait dengan bagaimana institusi media mendapatkan kapital finansial.

Pengamatan Knoche, dalam industri media pergerakan kapital-kapital media terus- menerus berlangsung, sejalan dengan tujuan alamiah kapitalisme yang berupaya memaksimalkan penciptaan surplus nilai (profit). Namun, sejalan dengan digitalisasi media, pergerakan kapital tersebut berjalan menuju pada kecenderungan pengintegrasian industri media atau menjadi industri media yang bercorak "universal" dari sebelumnya yang terpisahpisah. Universalisasi industri media semacam ini terjadi pada setiap level kapital dan institusi yang berpengaruh terhadap keseluruhan proses produksi media dan segenap fungsinya (Knoche, 1999). Universalisasi industri media dalam pandangan Knoche berwujud pada kemunculan berbagai korporasi multimedia yang dihasilkan dari transformasi perusahaan media tradisional, seperti institusi media cetak ataupun penyiaran.

Pola ekspansi kapital semacam ini dalam pendekatan ekonomi politik media sejalan dengan apa yang disebut sebagai proses spasialisasi (Mosco, 1996). Proses spasialisasi merujuk pada berbagai upaya yang dilakukan oleh kapitalis industri media dalam menghadapi hambatanhambatan ruang (spasial) dan waktu. Dalam hal ini, kecenderungan para pemilik kapital untuk menggunakan dan menyempurnakan sarana transportasi dan komunikasiuntuk mempersempit waktu dalam membawa barang, orang, maupun pesan melintasi ruang, dan dengan demikian mampu mempersempit signifikansi jarak spasial sebagai kendala bagi ekspansi kapital.

Spasialisasi dalam kajian ekonomi media berlangsung sebagai suatu strategi gerak pengkonsentrasian kapital yang ditujukan dalam penguasaan pasar industri. Penguasaan pasar industri dapat dilihat dari corak konsentrasi pasar industri media yang terbentuk, yaitu bagaimana konsentrasi kepemilikan (concentration of ownership) yang berlangsung (Picard, 1991; Albaran, 1996). Semakin terkonsentrasi kepemilikan media pada sebagian kecil para pemilik kapital maka struktur pasar yang terbentuk semakin bersifat oligopolistik. Bagi para penguasa kapital, dengan motif pencapaian surplus nilai yang maksimal, penciptaan pasar yang semakin terkonsentrasi menjadi tujuan. Hal semacam inilah yang menjadi strategi bagi para pemilik kapital untuk terus-menerus menggerakan kapitalnya melalui langkahlangkah ekspansi. Upaya ekspansi yang dilakukan berupa perluasan dan pengintegrasian kapital korporasi media secara horisontal (horizontal integration), integrasi vertikal (vertical integration), dan integrasi diagonal (cross-media integration).

Integrasi horisontal dilakukan sejalan dengan upaya penguasaan kapital industri media pada jenjang produksi yang sama. Dalam hal ini, suatu korporasi media yang bergerak dalam bisnis media cetak akan melakukan ekspansi kapital ke berbagai bidang usaha media cetak sejenis. Berbeda dengan pola pengintegrasian vertikal, pada pola demikian ekspansi kapital ditujukan pada lini produksi yang berjenjang. Suatu korporasi media cetak menjalankan strategi pengeintegrasian secara vertikal jika pengembangan kapital ditujukan dalam pendirian usaha yang mendukung produksi 
media cetak (kapital media-oriented), seperti pendirian percetakan, pendirian pabrik kertas, ataupun pembangunan infrastruktur media cetak (kapital media-infrastucture). Sementara dalam pola pengintegrasian diagonal (cross-media integration) perluasan kapital dilakukan baik secara horisontal maupun vertikal.

\section{Metode Penelitian}

Kajian ini bersifat eksploratif yang mencoba menelusuri gerak ekspansi kapital industri media di negeri ini. Terdapat 13 pemilik kapital media (grup korporasi media nasional) yang menjadi obyek kajian, yaitu: Grup Bali Post, Grup MRA, Grup Media, Grup Visi Media Asia, Grup Tempo Inti Media, Grup Femina, Grup Mahaka Media, Grup Global Mediacom, Grup CT Corp/CT Trans, Grup EMTEK, Grup Beritasatu Media Holding, Grup Kompas Gramedia, dan Grup Jawa Pos. Grup korporasi media tersebut merupakan penguasa pasar industri media di negeri ini.

Seluruh pelaku industri media dikaji dengan bersandar pada analisis ekonomi industri mediayang menitikberatkan pada analisis struktur pasar, khususnya pencermatan terhadap gerak ekspansi kapital industri yang terkonsentrasi pada berbagai bentuk integrasi kepemilikan kapital (horisontal, vertikal, maupun diagonal). Pencermatan terhadap pola konsentrasi kepemilikan dilakukan semenjak tahun 1998 hingga 2016 ini, untuk menggambarkan gerak perubahan dan perkembangan kapital sebagai strategi pengelolaan kapital para pelaku industri media.

\section{Hasil dan Pembahasan}

Liberalisasi politik dan perubahan teknologi semenjak tahun 1998 menjadi titik tolak pergerakan kapital korporasi media di negeri ini. Liberalisasi politik yang membebaskan berbagai barriers to entry industri, menjadi pendorong korporasi media menggerakkan kapital yang dimiliki untuk mendirikan, mengambil alih kepemilikan, ataupun menggabungkan kapital yang mereka miliki sehingga akumulasi kapital yang jauh lebih berdaya tercipta. Di sisi lain, arus perkembangan teknologi komunikasi yang terangkum dalam konsep digitalisasi media juga menjadi titik tolak grup korporasi media beradaptasi. Pola adaptasi dilakukan, sekaligus menjadi dasar ekspansi pengembangan model bisnis baru yang berorientasi pada media digital interaktif.

Penelusuran terhadap 13 grup korporasi media nasional menunjukkan, baik liberalisasi politik dan perkembangan teknologi secara simultan direspons dalam pola-pola ekspansi kapital. Gerak kapital setiap grup korporasi yang diteliti berjalan ke setiap lini pengintegrasian kapital, baik secara horisontal, vertikal, maupun diagonal. Pergerakan kapital tersebut terlihat sangat dinamis hanya pada satu dasawarsa perkembangan. Selepas itu, sebagian grup korporasi melambatkan gerak pengakumulasian kapitalnya. Sekalipun sebagian grup korporasi masih terlihat berekspansi akan tetapi tidak lagi sepesat era sebelumnya. Bahkan, terlihat kecenderungan memperluas pengelolaan kapitalnya pada sektor non media.

Terkait dengan pergerakan kapital yang berlangsung, setidaknya terdapat tiga format perubahan pengelolaan kapital yang terjadi pada seluruh grup korporasi media. Pertama, pada sebagian grup korporasi, setelah satu dasawarsa perkembangan kapital diikuti olehkecenderungan stagnasi ekspansi kapital. Dalam lima tahun terakhir, misalnya, terdapat grup korporasi yang hanya bertahan dalam pengelolaan kapital media yang dikuasainya. Grup Bali Pos, Grup MRA, Grup Media, Grup Visi Media Asia, menjadi bagian dari grup korporasi media yang kini hanya terfokus pada pengelolaan kapital media sebelumnya (Tabel 1).

Grup Bali Pos, semenjak beroperasi (1972) berkembang pesat dan menguasai pasar media di Bali. Dalam pengelolaan ABG Satria Naradha, akumulasi kapital membuat grup berekspansi di berbagai media cetak, terutama di tahun 1998 dengan menerbitkan berbagai tabloid. Selepas tahun 2001, gerak ekspansi Grup Bali Pos semakin meluas ke berbagai bidang 
media, khususnya dalam industri radio dan televisi ke berbagai kota besar seperti Surabaya, Jakarta, Bandung, Medan, hingga Aceh. Namun, selepas 2008, khususnya lima tahun terakhir ini tidak tampak gerak kapital yang signifikan pada kelompok media ini.

Situasi yang tidak jauh berbeda pada Grup MRA Media. Grup yang didirikan Soetikno Soedarjo, Adiguna Sutowo dan Dian M Soedardjo tahun 1993 ini semenjak tahun 2000 pesat berkembang, dalam bisnis pengelolaan stasiun radio dan jaringan majalah gaya hidup waralaba dunia pada berbagai segmen. Di samping itu, Grup MRA juga berdiversifikasi usaha di luar bidang media, seperti otomotif (distributor mobil Ferrari). Namun semenjak tahun 2008 pola ekspansi grup ini di media terhenti. Tahun 2016, terdapat upaya dari grup ini untuk berencara memasuki pasar bursa, sebagai tambahan kapital baru (CNN Indonesia, 11/02/2016).

Grup Media, yang dikendalikan oleh Surya Paloh, semenjak mengelola Media Indonesia (1989), gerak kepemilikan media berlanjut dengan menguasai beberapa surat kabar lokal dan menjadi puncaknya tatkala grup ini mengudarakan stasiun TV Metro (2000), yang mengkhususkan diri dalam segmen televisi berita. Selepas pendirian Metro, tidak terlihat gerak kapital grup media ini. Namun, selain bidang media grup ini bergerak dalam berbagai unit usaha industri pariwisata dengan kepemilikan beberapa hotel berbintang lima, jasa layanan catering, pertambangan marmer, hingga sektor perminyakan.

Grup Visi Media Asia dilekatkan pada keterlibatan konglomerasi bisnis sekaligus politisi nasional, Aburizal Bakrie bersama keluarganya, dalam pengelolaan media. Investasi dalam media tercatat sejalan dengan kepemilikan stasiun televisi ANTV (1993). Pengkonsentrasian kapital kepemilikan dilakukan secara horizontal dengan menguasai stasiun Televisi TVOne (2008). Di sisi lain, grup Visi Media Asia juga melakukan integrasi diagonal dengan pengoperasian media online Viva.co.id (2008). Selepas itu, gerak kapital grup korporasi ini dalam industri media $t$

Kedua, grup korporasi media yang berekspansi secara masif semenjak 1998, namun selepas satu dasa warsa pengembangan kapital justru menunjukkan kecenderungan perlambatan gerak ekspansi kapital medianya. Sekalipun menunjukkan perlambatan gerak ekspansi

Tabel 1. Stagnasi Gerak Kapital Grup Korporasi Media Nasional

\begin{tabular}{|c|c|c|c|c|c|}
\hline \multirow{2}{*}{$\begin{array}{l}\text { Korporasi } \\
\text { Media }\end{array}$} & \multirow[t]{2}{*}{ Periode } & \multicolumn{4}{|c|}{ Gerak Integrasi Kapital } \\
\hline & & Horisontal & Vertikal & Diagonal & Luar Media \\
\hline \multirow{2}{*}{ Grup Bali Post } & $1972-2008$ & 5 koran & 1 percetakan & $\begin{array}{l}4 \text { tabloid, } 8 \text { radio, } \\
9 \text { televisi, } 1 \text { online }\end{array}$ & $\begin{array}{l}3 \text { unit usaha \& } \\
\text { koperasi }\end{array}$ \\
\hline & 2009-2016 & - & - & - & - \\
\hline \multirow[t]{2}{*}{ Grup MRA } & 1993-2008 & 5 radio & - & $\begin{array}{l}9 \text { majalah, } \\
1 \text { online }\end{array}$ & $\begin{array}{l}\text { Jaringan resto \& } \\
\text { hotel, dan otomotif. }\end{array}$ \\
\hline & $2009-2016$ & - & - & - & - \\
\hline \multirow[t]{2}{*}{ Grup Media } & 1989-2008 & 2 koran & 1 percetakan & $\begin{array}{l}1 \text { televisi, } \\
2 \text { online }\end{array}$ & $\begin{array}{l}2 \text { jaringan hotel, } 1 \\
\text { catering, } 3 \text { energi } \\
\& \text { tambang. }\end{array}$ \\
\hline & 2009-2016 & - & - & - & - \\
\hline \multirow[t]{2}{*}{$\begin{array}{l}\text { Grup Visi Media } \\
\text { Asia }\end{array}$} & $1993-2008$ & 2 televisi & - & 1 online & $\begin{array}{l}53 \text { industri metal, } \\
37 \text { agro industri, } 4 \\
\text { pertambangan, } 3 \\
\text { telekomunikasi, } 34 \\
\text { properti }\end{array}$ \\
\hline & 2009-2016 & - & - & - & - \\
\hline
\end{tabular}

Sumber: Hasil inventarisasi dan pengolahan data kepemilikan berbagai jenis kapital media pada masing-masing grup korporasi media hingga Desember 2016. 
kapital, pada saat yang bersamaan grup korporasi ini mulai mencari peluang pengelolaan kapital pada sisi-sisi pendukung kapital media (kapital media-oriented) mereka seperti pemanfaatan komunitas pembaca, pendirian rumah kreatif, pendirian event organizer, dan sejenisnya. Grup Femina, Grup Tempo, Grup Mahaka Media, masuk dalam kelompok ini (Tabel 2).

Majalah Tempo yang terbit tahun 1970 menjadi salah satu titik awal penanda berkembangnya grup media Tempo Inti Media. Akan tetapi, peristiwa pembredelan 1994 menghadang langkah bisnis media. Tahun 1998, selepas dari runtuhnya rezim Orde Baru dan dimulainya liberalisasi pendirian media, Tempo hadir kembali dan sebagian saham dimiliki publik (perusahaan terbuka tahun 2001). Semenjak itu Tempo berekspansi memperluas pengintegrasian secara horisontal dan diagonal. Berbagai perluasan usaha yang memanfaatkan nilai brand Tempo mulai dilakukan seperti pendirian event organizer, komunitas, dan penerbitan inhouse bekerja sama dengan BUMN.

Grup Femina diawali dengan penerbitan Majalah Femina (1972) yang mengkhususkan produknya pada kalangan perempuan. Selanjutnya, dengan surplus kapital yang dimiliki, grup korporasi yang dikendalikan oleh keluarga Alisjahbana ini berekspansi secara horisontal, vertikal maupun diagonal. Bahkan, ekspansi usaha di luar industri media dilakukan sejalan dengan keterlibatan grup ini dalam usaha agribisnis. Namun, semenjak tahun 2007 grup ini mulai memperlambat ekspansi kapital medianya. Kecenderungannya, pengembangan kapital dilakukan dengan mendirikan berbagai unit usaha yang memanfaatkan jaringan dan komunitas.

Cikal bakal Grup Mahaka Media bermula dari pengambilalihan PT Abdi Bangsa penerbit Republika (terbit 1993). Tahun 2002, PT Abdi Bangsa menjadi perusahaan terbuka, dan menjadi Mahaka Media (2010), yang sahamnya dikuasai Erick Thohir. Perjalanan bisnis grup ini tergolong cukup ekspansif pada awalnya, sejalan pengakuisian berbagai media cetak, jaringan radio, dan televisi. Namun selepas tahun 2009, ekspansi kapital grup ini mulai terbatas, tertuju pada pendirian rumah produksi, jasa layanan kartu, dan tidak pada pendirian media baru.

Ketiga, grup-grup korporasi media yang masih menunjukkan perluasan kapital medianya sekalipun tidak seagresif pengelolaan kapital media mereka lima tahun yang lalu. Apabila

Tabel 2. Perlambatan Gerak Kapital Grup Korporasi Media Nasional

\begin{tabular}{|c|c|c|c|c|c|}
\hline \multirow{2}{*}{$\begin{array}{l}\text { Korporasi } \\
\text { Media }\end{array}$} & \multirow[t]{2}{*}{ Periode } & \multicolumn{4}{|c|}{ Gerak Integrasi Kapital } \\
\hline & & Horisontal & Vertikal & Diagonal & Luar Media \\
\hline \multirow[t]{2}{*}{ Grup Tempo } & $1970-2008$ & 2 majalah & $\begin{array}{l}1 \text { percetakan } \\
1 \text { pusat data }\end{array}$ & $\begin{array}{l}1 \text { koran } \\
1 \text { komunitas }\end{array}$ & \multirow[t]{2}{*}{-} \\
\hline & $2009-2016$ & 6 majalah & - & $\begin{array}{l}1 \mathrm{TV}, 2 \text { online, } \\
1 \text { event organizer, } \\
1 \text { tabloid. }\end{array}$ & \\
\hline \multirow[t]{2}{*}{ Grup Femina } & $1972-2008$ & 11 majalah & $\begin{array}{l}1 \text { percetakan } \\
1 \text { distribusi \& } \\
\text { marketing }\end{array}$ & $\begin{array}{l}1 \text { radio, } 1 \text { penerbit } \\
1 \text { rumah produksi } \\
5 \text { komunitas }\end{array}$ & \multirow[t]{2}{*}{1 agrobisnis } \\
\hline & $2009-2016$ & 2 majalah & & $\begin{array}{l}1 \text { e-commerce, } \\
\text { online publishing }\end{array}$ & \\
\hline \multirow[t]{2}{*}{$\begin{array}{l}\text { Grup Mahaka } \\
\text { Media }\end{array}$} & $1998-2008$ & 2 koran & 1 percetakan & $\begin{array}{l}1 \text { agen iklan, } 1 \\
\text { online, } 1 \text { majalah, } \\
1 \text { penerbitan, } 4 \\
\text { radio. }\end{array}$ & \multirow[t]{2}{*}{$\begin{array}{l}\text { bisnis sport, } \\
\text { jaringan restoran. }\end{array}$} \\
\hline & $2009-2016$ & - & & $\begin{array}{l}1 \text { radio, } 1 \text { rumah } \\
\text { produksi }\end{array}$ & \\
\hline
\end{tabular}

Sumber: Hasil inventarisasi dan pengolahan data kepemilikan berbagai jenis kapital media pada masing-masing grup korporasi media hingga Desember 2016. 
Tabel 3 Gerak Pertumbuhan Kapital Grup Korporasi Media Nasional

\begin{tabular}{|c|c|c|c|c|c|}
\hline \multirow{2}{*}{$\begin{array}{l}\text { Korporasi } \\
\text { Media }\end{array}$} & \multirow[t]{2}{*}{ Periode } & \multicolumn{4}{|c|}{ Gerak Integrasi Kapital } \\
\hline & & Horisontal & Vertikal & Diagonal & Luar Media \\
\hline \multirow[t]{2}{*}{$\begin{array}{l}\text { Grup Global } \\
\text { Mediacom }\end{array}$} & 1993-2008 & $\begin{array}{l}3 \mathrm{TV}, 3 \mathrm{TV} \\
\text { berbayar }\end{array}$ & $\begin{array}{l}1 \text { infrastruktur, } \\
2 \text { agen iklan, } 1 \\
\text { talent agen, } 4 \\
\text { rumah produksi }\end{array}$ & $\begin{array}{l}4 \text { jaringan radio, } \\
1 \text { koran, } 1 \text { tabloid, } \\
2 \text { majalah, lonline }\end{array}$ & \multirow{2}{*}{$\begin{array}{l}1 \text { institusi financial } \\
\text { service. } \\
7 \text { financial service, } \\
9 \text { institusi properti, } \\
3 \text { hotel dan resort, } 1 \\
\text { infrastruktur }\end{array}$} \\
\hline & 2009-2016 & $1 \mathrm{TV}$ & $\begin{array}{l}1 \text { distribusi, } \\
1 \text { publishing, } 1 \\
\text { rumah } \\
\text { prioduksi, }\end{array}$ & $\begin{array}{l}2 \text { tabloid, } 1 \\
\text { majalah, sosial } \\
\text { media, } 1 \text { game, } 1 \\
\text { internet provider, } \\
1 \text { e-commerce }\end{array}$ & \\
\hline \multirow{2}{*}{$\begin{array}{l}\text { Grup CT } \\
\text { Corp/Trans } \\
\text { Corpora }\end{array}$} & 2001-2008 & $2 \mathrm{TV}$ & $\begin{array}{l}1 \text { talent agen, } 1 \\
\text { rumah produksi }\end{array}$ & - & \multirow{2}{*}{$\begin{array}{l}\text { properti, mall, ritel, } \\
\text { keuangan, hotel \& } \\
\text { resort, theme park, } \\
\text { hipermarket. }\end{array}$} \\
\hline & 2009-2016 & $\begin{array}{l}1 \mathrm{TV}, 1 \mathrm{TV} \\
\text { berbayar }\end{array}$ & - & 2 online & \\
\hline \multirow{2}{*}{$\begin{array}{l}\text { Grup Elang } \\
\text { Mahkota } \\
\text { Teknologi } \\
\text { (EMTEK). }\end{array}$} & $1990-2008$ & $2 \mathrm{TV}$ & - & - & \multirow{2}{*}{$\begin{array}{l}5 \text { perdagangan \& } \\
\text { jasa solusi, } 1 \text { jasa } \\
\text { kesehatan }\end{array}$} \\
\hline & $2009-2016$ & $\begin{array}{l}1 \mathrm{TV}, 1 \mathrm{TV} \\
\text { berbayar }\end{array}$ & $\begin{array}{l}6 \text { rumah } \\
\text { produksi, } 2 \\
\text { infrastruktur, } 1 \\
\text { studio, } 3 \text { agensi }\end{array}$ & $\begin{array}{l}2 \text { online, } \\
4 \text { e-commerce }\end{array}$ & \\
\hline \multirow[t]{2}{*}{$\begin{array}{l}\text { Beritasatu Media } \\
\text { Holding }\end{array}$} & 1994-2008 & 1 TV kabel & - & $\begin{array}{l}3 \text { koran, } \\
2 \text { majalah }\end{array}$ & \multirow{2}{*}{$\begin{array}{l}3 \text { grup properti, } 3 \\
\text { grup keuangan, } 2 \\
\text { perdagangan, grup } \\
\text { teknologi, grup } \\
\text { investasi, grup } \\
\text { rumah sakit }\end{array}$} \\
\hline & $2009-2016$ & $1 \mathrm{TV}$ & 1 agensi iklan & $\begin{array}{l}2 \text { majalah, } \\
1 \text { online }\end{array}$ & \\
\hline
\end{tabular}

Sumber: Hasil inventarisasi dan pengolahan data kepemilikan berbagai jenis kapital media pada masing-masing grup korporasi media hingga Desember 2016.

dipilah pada kelompok grup korporasi media ini sebagian berasal dari pelaku pasar yang bukan berlatar belakang dari industri media. Grup Global Mediacom, Grup CT Corp/Trans Corpora, Grup EMTEK, Grup Beritasatu Media Holding menjadi bagian dari grup ini (Tabel 3).

Gerak kapital pada sebagian grup ini tidak hanya berupa pendirian atau pengakuisian kapital media (stasiun penyiaran televisi baru, media cetak, media online), mengembangkan kapital media-oriented, bahkan juga pengembangan kapital infrastruktur (infrastructure capital). Grup Global Mediacom menjadi korporasi media terintegrasi di Indonesia ketika di bawah kendali Hary Tanoesudibjo (1998). Grup ini berkembang sangat pesat berinvestasi di berbagai bidang industri media.

Aksi-aksi korporasi Global Mediacom selama ini, terutama semenjak tahun 2005, menunjukkan pengkonsentrasian kepemilikan media baik secara horisontal, vertikal, maupun diagonal. Selepas tahun 2008, sekalipun tidak seekspansif masa sebelumnya gerak kapital Global Mediacom berlanjut. Gerak kapital mengarah pada berbagai platform media terkait dengan teknologi, seperti dalam bentuk media online, sosial media, game, e-commerce, hingga internet provider .

Grup CT Corp atau Trans Corpora, diidentikkan dengan Chairul Tanjung, pengusaha yang juga sempat menjadi menteri koordinator perekonomian (2014). Pendirian Trans TV di tahun 2001 menjadi awal keterlibatan grup ini dalam media. Beberapa tahun setelahnya, penguasaan Trans Corpora dalam media semakin meluas, baik secara horisontal, vertikal, maupun diagonal. Pengambilalihan sebagian saham TV 7 (Trans 7) dari Grup Kompas Gramedia di tahun 2006 dan Detik.com tahun 2011 dan terakhir mendirikan CNN Indonesia (2015), menjadikan grup ini sebagai pemain utama industri media. Di luar bisnis media, Grup Trans Corpora bertumpu 
pada industri properti yang berpadu dengan hiburan, keuangan dan retail.

Grup Elang Mahkota Teknologi (EMTEK), sebelumnya bergerak dalam bidang teknologi informasi. Titik perubahan berlangsung saat EMTEK menguasai sahamsaham PT Surya Citra Media, Tbk (2001). EMTEK di bawah kendali Eddy K Sariaatmadja terus-menerus mengembangkan sayap bisnisnya dengan melakukan berbagai aksi korporasi berupa penggabungan usaha (merger) ataupun pengakuisisian.

Akuisisi televisi O'channel dari grup media MRA (2007), meluncurkan Nexmedia, stasiun televisi berbayar (2011), merger dengan Indosiar (2013). Tidak hanya berkutat pada stasiun televisi, EMTEK juga melebarkan pengaruhnya pada berbagai platform teknologi, seperti media online (melalui payung KMK Online dan Liputan6.com) dan dunia perdagangan e-commerce.

Kemunculan grup Beritasatu Media Holding (2011) menunjukkan upaya Grup Lippo memperluas jangkauan usahanya di bidang media. Grup ini berlatar bekalang korporasi di berbagai bidang, baik keuangan, asuransi, properti, retail, jasa pendidikan maupun kesehatan. Keterlibatan grup yang dikendalikan oleh keluarga Mochtar Riady (James Riady) di industri media sejalan dengan pembentukan Globe Media Group. Sebelumnya Lippo membangun berbagai unit bisnis yang terkait dengan infrastruktur media, seperti penyediaan jasa jaringan internet dan TV kabel. Teknologi menjadi acuan perkembangan grup ini. Pada tahun 2002, grup ini memasuki bisnis media cetak, memperluas dengan mendirikan berbagai majalah, mengambil alih kepemilikan surat kabar Suara Pembaruan, hingga mengoperasikan situs online Beritasatu.com yang terintegrasikan dengan televisi berlabel Beritasatu TV.

Apabila berbagai grup korporasi media di atas berlatar belakang bukan berasal dari mereka yang bergulat pada industri media, terdapat pula dua grup korporasi media: Grup Kompas Gramedia dan Grup Jawa Pos yang sejak awal didirikan oleh mereka yang berasal dari profesional media. Kedua grup media ini berkembang menjadi pemain utama pasar media, khususnya pasar industri media cetak (Tabel 4).

Titik pertumbuhan grup korporasi Kompas Gramedia tahun 1965, sejalan dengan kehadiran Surat Kabar Kompas. Sejak tahun 1970, para pendirinya: Jacob Oetama, PK Ojong,

Tabel 4. Gerak Pertumbuhan Kapital Grup Korporasi Media Nasional

\begin{tabular}{|c|c|c|c|c|c|}
\hline \multirow{2}{*}{$\begin{array}{l}\text { Korporasi } \\
\text { Media }\end{array}$} & \multirow[t]{2}{*}{ Periode } & \multicolumn{4}{|c|}{ Gerak Integrasi Kapital } \\
\hline & & Horisontal & Vertikal & Diagonal & Luar Media \\
\hline \multirow[t]{2}{*}{$\begin{array}{l}\text { Grup Kompas } \\
\text { Gramedia }\end{array}$} & $1965-2008$ & 16 koran & $\begin{array}{l}2 \text { grup } \\
\text { percetakan, } 1 \\
\text { agensi iklan, } 1 \\
\text { distribusi. }\end{array}$ & $\begin{array}{l}111 \text { toko buku, } \\
\text { jaringan radio, } 12 \\
\text { majalah, } 4 \\
\text { tabloid, } 6 \text { grup } \\
\text { penerbitan, } 1 \\
\text { online. }\end{array}$ & \multirow{2}{*}{$\begin{array}{l}53 \text { hotel, } 1 \text { lembaga } \\
\text { pendidikan, } 1 \\
\text { universitas, } 1 \text { grup } \\
\text { industri tissue, } 1 \\
\text { grup event } \\
\text { organizer, } 1 \text { grup } \\
\text { properti/ } \\
\text { infrastruktur tol }\end{array}$} \\
\hline & $2009-2016$ & 7 koran & - & $\begin{array}{l}1 \text { rumah produksi, } \\
1 \text { grup jaringan } \\
\text { TV, 1 TV } \\
\text { berbayar, } 2 \text { online }\end{array}$ & \\
\hline \multirow[t]{2}{*}{ Grup Jawa Pos } & $1982-2008$ & 100 koran & $\begin{array}{l}\text { grup pabrik } \\
\text { kertas, grup } \\
\text { percetakan, } \\
\text { lenergi listrik }\end{array}$ & $\begin{array}{l}13 \text { tabloid, } 2 \\
\text { majalah, } 4 \text { grup } \\
\text { media online, TV } \\
\text { jaringan }\end{array}$ & - \\
\hline & 2009-2016 & 10-27 koran & & $\begin{array}{l}46 \mathrm{TV} \text { jaringan, } 1 \\
\text { Internet provider }\end{array}$ & 1 grup properti \\
\hline
\end{tabular}

Sumber: Hasil inventarisasi dan pengolahan data kepemilikan berbagai jenis kapital media pada masing-masing grup korporasi media hingga Desember 2016. 
dan beberapa tokoh politik nasional yang menjadi pemegang saham berekspansi lebih agresif dengan mendirikan berbagai media. Dalam perjalanan bisnis selanjutnya, korporasi media ini pun berekspansi ke berbagai bidang usaha yang masih terkait ataupun yang tidak terkait langsung dengan industri media. Selepas tahun 1997, pola ekspansi grup ini tidak menyurut. Di satu sisi, pengembangan usaha media cetak baru dilakukan dan di sisi lain pola ekspansi grup ini semakin meluas pada bidang-bidang non media, seperti jaringan hotel, pendidikan, hingga infrastruktur.

Surat kabar Jawa Pos (1982) mengawali Grup Jawa Pos. Dalam pengelolaan Dahlan Iskan kisah sukses pertumbuhan kapital Jawa Pos dan pola-pola ekspansi masif grup ini berlangsung. Apabila sebelumnya, grup ini hanya menguasai pasar pembaca maupun iklan media cetak di Jawa Timur, selepas krisis ekonomi 1998 dimanfaatkan grup ini untuk memperluas secara nasional. Beragam pola strategi penetrasi pasar dilakukan, di antaranya melalui pengakuisisian atau mengambil alih kepemilikan media cetak daerah yang secara bisnis tidak sehat hingga pendirian media baru. Selepas tahun 1998 hingga kini, dalam catatan grup ini di awal tahun 2015, sudah 195 penerbitan dalam pengelolaan grup Jawa Pos yang tersebar membentuk jaringan di seluruh Indonesia dengan perusahaanperusahaan berartribusi "Intermedia Pers". Selepas tahun 1998 berbagai perluasan bisnis ke berbagai bidang usaha media (cross media integration) juga dilakukan, berupa pendirian jaringan televisi Jawa Pos TV (2002). Hingga akhir 2015 sekitar 46 stasiun lokal dikelola. Grup ini juga mulai berinvestasi dalam berbagai poyek investasi properti di Jawa Timur, Kalimantan, dan Jabotabek (2013).

\section{Simpulan}

Penelusuran terhadap gerak kapital dari 13 grup korporasi media nasional di negeri ini menunjukkan adanya dinamika substansial pola-pola pengakumulasian kapital. Di satu sisi, liberalisasi politik dan perubahan teknologi komunikasi (digitalisasi media) memperlancar gerak kapital setiap korporasi media di negeri ini, menjadi titik tolak perluasan usaha yang berorientasi pada penciptaan suplus nilai produksi. Liberalisasi politik dan digitalisasi media juga menjadi titik tolak pola-pola pengintegrasian kepemilikan media baik secara horisontal, vertikal, maupun diagonal. Dua faktor yang mendasari gerak kapital media itu sangat berperan pada setiap korporasi media yang dikaji.

Namun, pada sisi lain hasil kajian ini menunjukkan, hingga satu dasa warsa kemudian, cenderung terjadi perubahan pola dan orientasi gerak perluasan kapital. Terdapat tiga format, yaitu kelompok grup korporasi yang gerak kapitalnya cenderung stagnan, grup korporasi yang cenderung melambat dan berupaya beralih pada pengelolaan kapital dengan memanfaatkan nilai tambah pengelolaan kapital turunan industri media, dan grup korporasi yang tetap berekspansi pada industri media dan industri lainnya kendati dilakukan dalam skala terbatas.

Perubahan gerak kapital selepas satu dasa warsa ekspansi yang masif, berlangsung karena beragam faktor. Kondisi ekonomi global yang melambat semenjak 2007-2008 ditenggarai turut berpengaruh. Perlambatan ekonomi global pada mulanya merupakan persoalan krisis finansial lembaga-lembaga keuangan di negara-negara perekonomian besar seperti Amerika Serikat dan persoalan lonjakan harga energi minyak dunia. Memasuki tahun 2008, perlambatan ekonomi dan lonjakan harga energi minyak dunia sudah mengancam kehancuran berbagai sektor ekonomi dunia. Perekonomian Indonesia sekalipun saat itu dalam kondisi yang dikatakan relatif terkendali, turut pula terpengaruh. Tidak hanya pada pasar finansial ataupun sektorsektor produksi berorientasi ekspor kepada negara-negara lain, namun juga berpengaruh terhadap sektor riil yang berkaitan langsung dengan produksi maupun konsumsi masyarakat (Kompas, 24/3/2008).

Namun, bagi industri media, perlambatan ekonomi global di tahun 2008 belum berimplikasi 
panjang pada terjadinya krisis ekonomi, terutama krisis yang berlangsung pada pasar periklanan. Sebagai gambaran, pada tahun 2008 sumber-sumber kapital yang diperoleh dari pasar iklan media justru menunjukkan pertumbuhan hingga 22 persen dibandingkan pada tahun 2007 (Kompas, 5/12/2008). Padahal, perlambatan ekonomi global saat itu secara langsung sudah mempengaruhi kenaikan harga-harga barang kebutuhan konsumsi masyarakat dan hargaharga bahan kebutuhan produksi industri media. Data BPS (2009) menunjukkan, inflasi tahun 2008 menjadi 11,8 persen, angka inflasi tertinggi selepas krisis ekonomi 1997/1998. Berbeda dengan kondisi krisis ekonomi 1997, perlambatan ekonomi 2008 terlihat belum sampai pada kondisi kerusakan dan penghentian segenap aktivitas ekonomi. Memang, situasi demikian membuat sebagian besar pelaku industri merekalkulasi tidak hanya pada sisi pola produksi dan terhadap pola investasi kapital mereka (Prasetyo, 2012).

Pada sisi lain, perubahan gerak kapital masing-masing pelaku industri media disebabkan karena semakin terbatasnya peluang dalam memperbesar ruang gerak media. Dahlan Iskan (2017) misalnya, mengungkapkan bahwa semenjak 2008 perluasan Grup Jawa Pos dalam produk kapital media cetak sudah sampai pada lingkup terkecil dari pasar pembaca surat kabar (kabupaten dan kota). Peluang ekspansi kapital selanjutnya lebih tertuju pada format kapital media lainnya, seperti memperluas jaringan televisi lokal. Bagi korporasi media lainnya, cenderung lebih memilih pada pengembangan kapital media digital (media online) atau bagi para pelaku industri seperti Grup Tempo Inti Media, Grup Femina, dan beberapa grup korporasi media lainnya memilih meningkatkan nilai tambah produk off-print di luar produk inti mereka.

Berbagai kondisi yang ditunjukkan oleh gerak kapital industri media mengindikasikan ruang persoalan baru bagi masa depan industri media di negeri ini. Di satu sisi, perlambatan gerak kapital menunjukkan ancaman persoalan stagnasi kapital industri media. Dugaan semakin menyusutnya surplus nilai yang dihasilkan industri ini sehingga menjadi penghambat penciptaan kapital baru semakin menguat. Adanya kecenderungan grup korporasi mendiversifikasikan kapitalnya pada unitunit bisnis di luar industri media semakin memperkuat dugaan pelemahan surplus nilai industri tersebut. Dugaan semacam ini semakin menguatkan anggapan masa senjakala media tengah berlangsung di negeri ini.

Di sisi lain, perlambatan gerak kapital menjadi semakin relatif jika dikaitkan dengan berbagai aksi korporasi grup media yang tetap berekspansi meskipun terbatas. Fakta juga menunjukkan, penciptaan suplus nilai poduksi masih berlangsung pada grup usaha ini (dijumpai pada grup-grup media penguasa pasar industri media) yang memungkinkan perluasan kapital pada format-format kapital media lainnya masih berlangsung. Kondisi demikian memperkuat pola-pola evolusi persaingan media yang menghantarkan sekelompok kecil grup korporasi ini (oligopolis) semakin menjadi penguasa industri media di negeri ini. Indikasi semacam ini membuka ruang baru kehidupan pasar industri media di negeri ini yang semakin bersifat oligopolistik, sekaligus juga membuka peluang munculnya kajian-kajian baru industri media untuk membuktikannya.

\section{Daftar Pustaka}

Albarran, B Alan. (1996). Media Economics: Understanding Markets, Industries and Concepts. Iowa: Iowa State University Press. Armando, Ade. (2016). Televisi Indonesia di Bawah Kapitalisme Global. Jakarta: Penerbit Buku Kompas. McChesney, RW. (2008). The Political Economy of Media: Enduring Issues, Emerging Dilemmas. New York: Monthly Reviews Press. de Sola Pool I. (1983). Technologies of Freedom: On Free Speech in an Electronic Age. Cambridge, UK: Harvard University Press. 
Deuze, M. (2004). What is Multimedia Journalism?.

Journalism

$\begin{array}{llll}\text { Studies } & 5 & \text { (2): } & \text { 237-255 }\end{array}$

Dewan Pers. (2015). Data Pers Nasional $2015 . \quad$ Jakarta.

Dhakidae, Daniel. (1991). The State, The Rise of Capital and The Fall of Political Journalism. Political Economy of Indonesian News Industry. Disertasi Cornell University, tidak diterbitkan. Hanazaki, Yasuo. (1998). Pers Terjebak. Institut Studi Arus Informasi.

Ishadi, SK. (2002). Praktek-praktek Diskursus di Ruang Pemberitaan RCTI, SCTV, Indosiar: Analisis Kritis Prosesproses Produksi Teks Berita Menjelang BerakhirnyaPemerintahanSoeharto(Mei 1998). Disertasi Universitas Indonesia.

Jenkins, Henry. (2006). Convergence Culture: Where Old and New Media Collide. New York: NYU Knoche, Manfred. (1999). The Media Industry's Structural Transformation in Capitalism and The Role of the State: Media Economics in the Age of Digital Communications. Triple C 14 (1): 1-47.

Kellner, D. (1990). Critical Theory, Marxism and Modernity. Cambridge, UK: Polity.

Lim, Merlyna, (2012). The League of Thirteen Media Concentration in Indonesia. Participatory Media Lab, Arizona State University \& Ford Foundation.

Luxemburg (2003). The Accumulation of Capital. London: Routledge.

Marx, Karl. (1992). Capital: A Critique of Political Economy: The Process of Circulation of Capital. Penguin Classics Mosco, Vincent. (1996, 2009). The Political Economy of Communication. London: Sage. Murdock, Graham, (1990). Redrawing the Map of the Concentration and Ownership in the Era of Privatization, in Marjorie Ferguson (ed), Public Communication-The New Imperatives: Future Directions for Media
Research. London: Sage Publications. Nainggolan, Bestian (2015). Konglomerasi Media Nasional: Tipologi, Konsentrasi, dan Kompetisi Pasar, dalam Menegakkan Kedaulatan Komunikasi. Jakarta: ISKI Negroponte, Nicholas. (1979). Being Digital. New York: Alfred A. Knopf. Nugroho, Y., Putri, DA., Laksmi, S, (2012). Memetakan Lanskap Industri Media Kontemporer di Indonesia (Edisi Bahasa Indonesia). Laporan. Jakarta: CIPG dan HIVOS.

Picard, R.G, (1989). Media Economics. Beverly Hills: Sage.

Schiller, Herbert. (1969). Mass Communication and American Empire. Boston: August M Kelley. Soo Chon, B., Chi JH., Barnett, GA., Danowski, JA dan Joo, SH. (2003). A Structural Analysis of Media Convergence: Cross Industry Mergers and Acquisitions in Information Industries. Journal of Media $\begin{array}{lll}\text { Economics } & 16 & \text { (3): } 141-157\end{array}$ Suarez, LV. (2009), (2012). Technocapitalism: A Critical Perspective on Technological Innovation and Corporatism. Philadelphia: Temple University Press.

Sen, Krishna; David T.Hill. (2000). Media, Culture and Politics in Indonesia. Melbourne: Oxford University Press.

Triputra, Pinckey. (2004). Dilema Industri Penyiaran di Indonesia: Studi tentang Neoliberalisme dan Perkembangan Pertelevisian di Era Orde Baru dan Reformasi. Disertasi Universitas Indonesia.

Wirtz, BW. (2001). Reconfiguration of Value Chains in Coverging Media and Communication Market. Long Range Planning 34 (4): 489-506 